\title{
Penguatan Pendidikan Karakter (PPK) Terintegrasi dalam Pembelajaran bagi Guru SD di Desa Ambengan
}

\author{
I Gede Astawan ${ }^{*}$, Ni Kadek Eva Krishna Adnyani², Nice Maylani Asril33, Luh Ayu \\ Tirtayani ${ }^{4}$ iD \\ 1,2,3,4 Fakultas Ilmu Pendidikan, Universitas Pendidikan Ganesha, Singaraja, Indonesia \\ *Corresponding author: astawan@undiksha.ac.id
}

\begin{abstract}
Abstrak
Desa Ambengan adalah salah satu desa di Bali yang letaknya di daerah perbukitan memiliki udara yang sangat sejuk serta pemandangan alam yang indah dan alami yang menjadi daya tarik wisatawan asing dan lokal datang menikmati keindahan desa. Dalam bidang pendidikan, di desa Ambengan terdapat 3 sekolah dasar. Penguatan Pendidikan Karakter (PPK) pada sekolah di desa Ambengan hanya diimplementasikan melalui kegiatan nonmengajar. Faktor utama PPK hanya diimplementasikan melalui kegiatan nonmengajar karena guru belum memiliki kesiapan untuk mengintegrasikan PPK dalam pembelajaran. Maka dari itu, pengabdian kepada masyarakat ini bertujuan untuk meningkatkan pemahaman dan melatih guru di SD Negeri di Desa Ambengan tentang pengintegrasian Penguatan Pendidikan Karakter (PPK) dalam pembelajaran. Kegiatan dilaksanakan dengan metode workshop dan pendampingan yang diikuti oleh 20 orang guru SD dan kepala satuan pendidikan di SD Negeri 2 Ambengan. Data dikumpulkan dengan metode angket dan dianalisis secara deskriptif. Hasil kegiatan pengabdian ini menunjukkan bahwa guru mampu memahami dengan baik konsep PPK dan mampu menyusun Rencana Pelaksanaan Pembelajaran (RPP) dengan mengintegrasikan PPK. Harapannya, pelatihan pengintegrasian PPK dalam pembelajaran bagi guru SD dapat dilaksanakan secara berkelanjutan guna menunjang pembelajaran yang bermanfaat.
\end{abstract}

Kata Kunci: Model Pembelajaran, Penguatan Pendidikan Karakter, Rencana Pelaksanaan Pembelajaran

\section{Abstract}

Ambengan Village is one of the villages in Bali which is located in a hilly area. This village has very cool air, beautiful, and natural scenery that attracts foreign and local tourists to come to enjoy the beauty of the village. Ambengan village has 3 elementary schools. Penguatan Pendidikan Karakter (PPK) in elementary school in Ambengan' village are only implemented through non-teaching activities. The main factor of PPK is only implemented through non-teaching activities because teachers do not yet have the readiness to integrate PPK in learning. Therefore, this community service aims to increase understanding and train teachers at elementary schools in Ambengan Village about integrating Penguatan Pendidikan Karakter (PPK) in learning process. The activity was carried out using a workshop and mentoring method which was attended by 20 of elementary school teachers and the head of education unit at SD Negeri 2 Ambengan. The data were collected by questionnaire method and analyzed descriptively. The results of this activity show that teachers are able to understand well the concept of PPK and are able to develop Rencana Pelaksanaan Pembelajaran (RPP) by integrating PPK. It is expected that this training can be carried out continuously to support the useful learning.

Keywords: Learning Models, Strengthening Character Education, Learning Implementation Plans

\section{PENDAHULUAN}

Seiring dengan perkembangan zaman, guru dituntut untuk terus belajar dan adaptif, sehingga bisa menjadi seorang guru yang professional dan dapat menjadi sosok yang patut diteladani oleh siswa (Aini \& Syamwil, 2020; Jamin, 2018; Sutisna et al., 2019). Pembelajaran yang dilakukan oleh guru sangat baik apabila sejalan dengan upaya yang sedang dan telah dilaksanakan oleh pemerintah. Salah satu kebijakan pemerintah yang perlu didukung pada jenjang pendidikan di SD adalah adanya program strategis yaitu Penguatan Pendidikan Karakter (PPK). PPK merupakan gerakan nasional yang dicanangkan pemerintah

History:

Received : September 10, 2021

Revised : : September 12, 2021

Accepted : November 03, 2021

Published : November 25, 2021
Publisher: Undiksha Press

Licensed: This work is licensed under

a Creative Commons Attribution 4.0 License

(c) (i) (?) 
melalui pendidikan di sekolah untuk membentuk generasi emas Indonesia pada tahun 2045 (Agung, 2017; Chrisyarani \& Yasa, 2018; Khotimah, 2019). Generasi emas ditandai dengan generasi yang memiliki karakter mulia di samping unggul dalam ipteks. PPK ini sangat penting ditanamkan sejak anak usia SD, sehingga anak-anak memiliki pondasi karakter yang kuat sejalan dengan pertumbuhan dan perkembangannya, baik fisik maupun mentalnya (Benninga et al., 2013; Çubukçu, 2012; Muchtar \& Suryani, 2019).

Guru profesional adalah guru yang menguasai empat jenis kompetensi, yaitu kompetensi akademik, kompetensi pedagogik, kompetensi sosial, dan kompetensi kepribadian (Akhwani \& Rahayu, 2021; Bagou \& Suking, 2020; Jamin, 2018). Keempat jenis kompetensi tersebut harus dikembangkan secara seimbang, sehingga guru dapat menjadi sosok yang patut diteladani oleh siswa. Selain itu, PPK juga bisa menjadi suatu bentuk pencegahan degradasi moral di masa-masa mendatang, Untuk itu, PPK ini harus segara diimplementasikan di sekolah-sekolah. Hasil penelitian sebelumnya menunjukkan bahwa perangkat pembelajaran IPA SD bermuatan kearifan lokal Tri Kaya Parisudha dapat meningkatkan keterampilan proses dan menanamkan nilai karakter (Astawan, 2018). Penerapan model pembelajaran trikaya parisudha dapat berdampak positif terhadap capaian pembelajaran siswa (Artawan \& Ardiawan, 2018; Artini et al., 2016; Widiasih et al., 2019).

Namun, masih banyak guru di sekolah dasar yang belum mengintegrasikan PPK ke dalam pembelajaran. Contohnya, sekolah di Desa Ambengan adalah salah satu desa di Kecamatan Sukasada, Buleleng, Provinsi Bali, Indonesia. Desa Ambengan, secara geografis posisinya di atas bukit hijau yang berjarak sekitar $6 \mathrm{~km}$ sebelah selatan kota Singaraja. Karena letaknya di daerah perbukitan, udara di desa Ambengan sangat sejuk sepanjang hari. Pemandangan alam yang indah dan alami menjadi ketertarikan bagi wisatawan asing dan lokal datang menikmati keindahan desa. Di Desa Ambengan terdapat 3 Sekolah Dasar (SD), yaitu SD 1 Ambengan, SD 2 Ambengan, dan SD 3 Ambengan. Penguatan Pendidikan Karakter (PPK) di ketiga sekolah dasar tersebut hanya diimplementasikan melalui kegiatankegiatan nonmengajar, seperti pembinaan ekstrakurikuler, upacara bendera, menegakan tata tertib, dan lain-lain. Belum ada pengintegrasian PPK di dalam pembelajaran. Faktor utama PPK hanya diimplementasikan melalui kegiatan nonmengajar karena guru belum memiliki kesiapan untuk mengintegrasikan PPK dalam pembelajaran. Selain itu, selama ini guru juga tidak pernah mendapatkan edukasi atau pelatihan tentang pentingnya pendidikan penguatan karakter bagi siswa dan cara mengintegrasikan PPK ke dalam kegiatan pembelajaran.

Maka dari itu, untuk mendukung terciptanya pembelajaran yang baik sudah seyogyanya pihak-pihak yang terkait turut membantu membekali guru dengan kompetensi yang memadai, utamanya dalam melaksanakan proses pembelajaran yang lebih baik. Undiksha sebagai LPTK pencetak sumber daya guru memiliki tanggung jawab besar turut andil mengembangkan kualitas profesi guru, di antaranya melalui kegiatan pengabdian kepada masyarakat (guru). Pengabdian masyarakat untuk guru sangat penting dilakukan dalam kaitanyan mengembangkan profesionalisme guru secara berkelanjutan. Salah satu langkah nyata yang dapat dilakukan adalah melalui kegiatan pengabdian kepada masyarakat. Dengan pelatihan ini, diyakini bahwa guru-guru di sekolah akan dapat melaksanakan PPK melalui pengintegrasian dalam pembelajaran. Dalam pelatihan ini, sekolah mitra adalah sekolah dasar yang ada di Desa Ambengan yang difokuskan di SD 2 Ambengan. Dengan potensi yang dimiliki oleh Desa Ambengan, sekolah harus mengambil peran dalam kaitannya dengan pendidikan. Sampai saat ini, berdasarkan wawancara dengan kepala sekolah dan sejumlah guru sebagai calon mitra menyatakan bahwa mitra sangat tertarik dan membutuhkan program pengabdian masyarakat ini, sehingga dapat melengkapi program PPK yang telah dilaksanakan selama ini di sekolah. Tujuan pelatihan ini adalah untuk meningkatkan pemahaman guru SD di Desa Ambengan tentang pentingnya Penguatan Pendidikan Karakter (PPK) bagi siswa sekolah dasar. Dan yang terpenting bisa melatih guru 
di SD Negeri di Desa Ambengan tentang cara pengintegrasian Penguatan Pendidikan Karakter (PPK) dalam pembelajaran.

\section{METODE}

Kegiatan pengabdian pada masyarakat ini dirancang dalam waktu 2 bulan. Kegiatan mulai dilaksanakan dari bulan Juli sampai Agustus 2021. Lokasi dari kegiatan pengabdian ini adalah di SD N 2 Ambengan. Namun mengingat kegiatan ini dilaksanakan di masa PPKM, maka kegiatan ini dilakukan secara daring. Partisipan / masyarakat sasaran dalam kegiatan pengabdian ini adalah guru yang berasal dari SD Negeri 2 di Desa Ambengan dengan total jumlah sebanyak 20 guru. Metode pelaksanaan diilustrasikan melalui kerangka pemecahan masalah yang diterapkan dalam kegiatan pengabdian pada masyarakat ini disajikan pada Gambar 1.

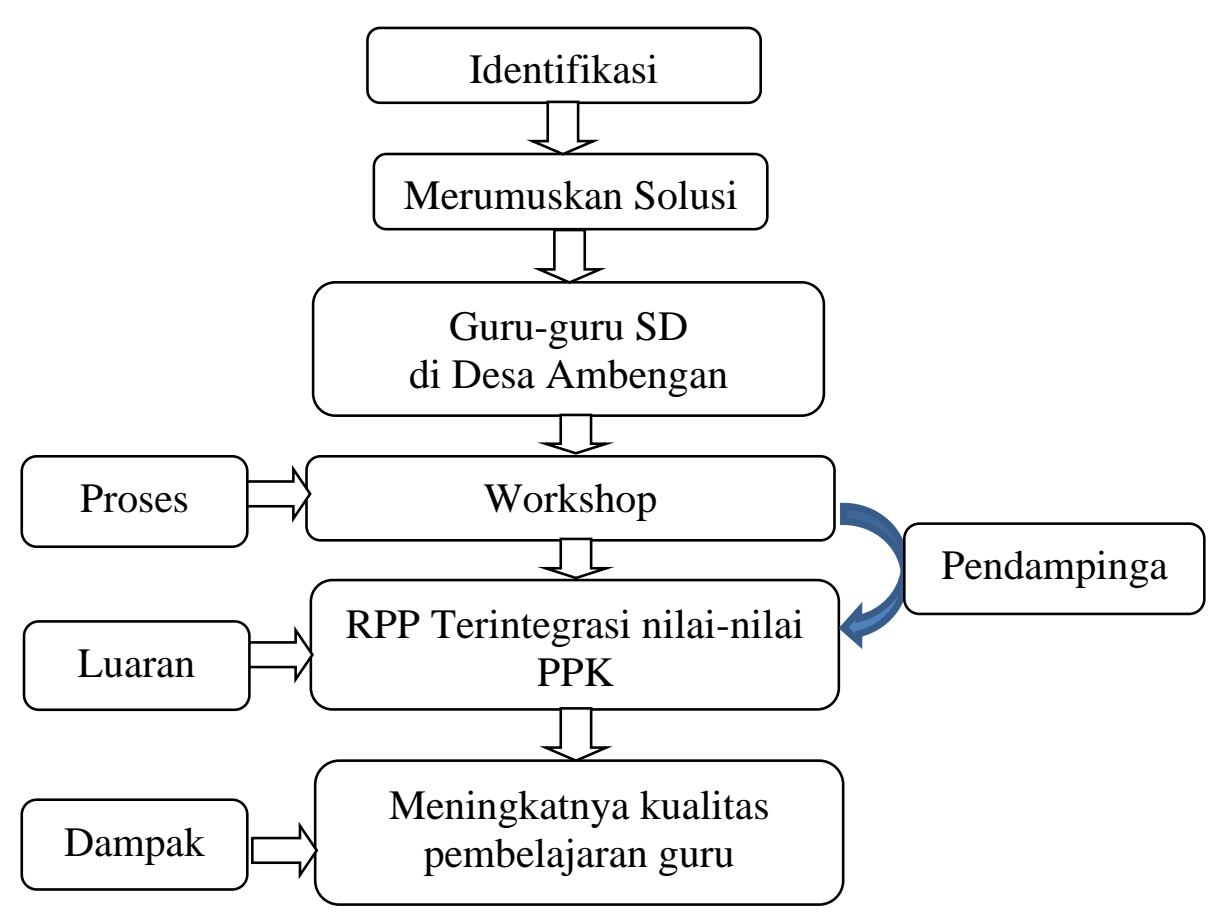

Gambar 1. Metode Pelaksanaan Skema Pemecahan Masalah

Kegiatan pertama dimulai dengan melakukan identifikasi masalah. Setelah masalah teridentifikasi, selanjutnya dirumuskan solusi pemecahannya. Dalam kegiatan pengabdian masyarakat ini solusinya melalui pelatihan penguatan pendidikan karakter terintegrasi pembelajaran.. Setelah melakukan identifikasi masalah dan menyepakati solusi, dilakukan diskusi tentang bentuk kegiatan. Setelah melakukan diskusi, dilanjutkan dengan workshop. Berdasarkan kerangka pemecahan masalah di atas, maka metode pelaksanaan kegiatan pengabdian pada masyarakat ini adalah menggunakan metode workshop dan pendampinan. Workshop berkaitan dengan penyusunan perangkat pembelajaran terintegrasi PPK. Kegiatan selanjutnya dilakukan pendampingan untuk memastikan perangkat yang disusun dapat diimplementasikan dengan baik. 


\section{HASIL DAN PEMBAHASAN}

\section{Hasil}

Kegiatan dimulai dengan penyajian materi oleh narasumber. Narasumber pertama membawakan materi tentang pendidikan karakter di sekolah. Narasumber kedua membawakan materi tentang penguatan pendidikan karakter terintegrasi dalam pembelajaran. Setelah narasumber selesai menyajikan, dilanjutkan dengan tanya jawab. Kegiatan dilanjutkan dengan sesi pelatihan, yaitu menyusun Rencana Pelaksanaan Pembelajaran (RPP) berdasarkan konsep model pembelajaran inovatif. Pada kegiatan ini, partisipan mampu menghasilkan draf kasar rancangan Rencana Pelaksanaan Pembelajaran (RPP), yang belum berupa hasil final. Setelah selesai menyusun draf RPP, kemudian sesuai kesepakatan, draf tersebut dilanjutkan dikerjakan di rumah masing-masing, tetapi tim P2M tetap melakukan pendampingan. Pendampingan secara terjadwal dilaksanakan pada tanggal 11 sampai dengan 13 Agustus 2021. Namun demikian, pendampingan dilayani setiap saat apabila peserta memerlukan konsultasi lewat online, yaitu WA.

Salah satu faktor sukses pembelajaran ditentukan oleh model pembelajaran yang diterapkan guru. Model pembelajaran mengacu pada pendekatan pembelajaran yang digunakan, termasuk di dalamnya tujuan-tujuan pembelajaran, tahap-tahap dalam kegiatan pembelajaran, lingkungan belajar, dan pengelolaan kelas (Law \& Kelton, 1991; Suyono \& Hariyanto, 2015; Yang et al., 2005). Model pembelajaran adalah suatu rencana atau pola yang dapat digunakan untuk membangun kurikulum, merancang bahan pembelajaran yang diperlukan, serta untuk memandu pembelajaran di dalam kelas atau pada situasi pembelajaran yang lain (Joyce et al., 2016). Model pembelajaran sebagai suatu pendekatan khusus dalam pembelajaran yang meliputi tujuan, sintaks, lingkungan, dan pengelolaan kelasnya (Mahmudah, 2018; Minsih, 2018; Mutiaramses et al., 2021). Berdasarkan pengertian tersebut, dapat disimpulkan bahwa model pembelajaran merupakan suatu rencana pembelajaran yang disusun secara sistematis dengan urutan langkah-langkah yang mudah diikuti dalam upaya pengelolaan kelas yang efektif untuk mencapai tujuan belajar.

Penguatan Pendidikan Karakter (PPK) terintegrasi dalam pembelajaran dapat dilakukan melalui dua hal, yaitu metodologi pembelajaran dan materi mata pelajaran (Adeyemi et al., 2009; La ode Onde et al., 2020; Sari \& Firman, 2019; Tristanti et al., 2021; Zubaidah, 2019). Pengintegrasian PPK melalui metodologi pembelajaran dengan menggunakan model-model pembelajaran inovatif. Model-model pembelajaran inovatif yang dapat dipilih di antaranya model pembelajaran kuantum, model pembelajaran berbasis proyek, model pembelajaran berbasis masalah, model pembelajaran berbasis otak, model pembelajaran berbasis kecerdasan ganda, model pembelajaran tri kaya parisudha, dan lainlain (Rahayu \& Firmansyah, 2019; Tibahary \& Muliana, 2018; Yuliati \& Lestari, 2018). Setiap model tersebut memiliki sintaks tersendiri Melalui sintaks model tersebut PPK diintegrasikan (La ode Onde et al., 2020; Mahardika et al., 2017; Rahmadani, 2019).

Di samping itu, pengintegrasian PPK melalui materi muatan mata pelajaran dapat disesuaikan dengan jenis muatan mata pelajarannya, misalnya muatan mata pelajaran IPA. Ketika membelajarkan materi tumbuhan, misalnya pohon kelapa, terlebih dahulu dijelaskan anatomi pohon kelapa. Pohon kelapa memiliki nama latin cocos nucifera. Pohon ini ini merupakan tanaman termasuk ke dalam suku pinang-pinangan (arecaceae). Batang pohon kelapa umumnya batang tunggal. Pohon kelapa memiliki akar serabut, tebal, dan berkayu membentuk bonggol. Daun pohon kelapa tersusun majemuk, menyirip sejajar tunggal, ketika masih muda berwarna kekuningan, dan ketika sudah tua berwarna hijau tua. Tinggi pohon kelapa bisa mencapai 30 meter. PPK dalam materi ini dapat diimplementasikan dengan menjelasakan semua bagian pohon kelapa mulai dari akar, batang, sampai daunnya bisa bermanfaat bagi siapa saja. Artinya, jadikanlah diri kita berguna bagi lingkungan di sekeliling kita. Bukankah kita juga sudah diingatkan bahwa sebaik-baiknya manusia adalah 
bermanfaat bagi orang lain. Bahkan, bukan hanya memberikan manfaat bagi manusia lainnya saja, tetapi juga memberikan manfaat bagi lingkungan alam. Karakter: Cinta kasih, peduli sesama, dan peduli lingkungan. Berdasarkan kegiatan yang telah dilakukan dan indikator keberhasilan yang telah ditetapkan, dapat disimpulkan hal-hal sebagai berikut: 1) meningkatkan pemahaman guru-guru SD di Desa Ambengan tentang konsep pendidikan karakter, dan 2) guru-guru SD di Desa Ambengan memiliki kemampuan yang cukup baik dalam mengintegrasikan PPK.

\section{SIMPULAN DAN SARAN}

Berdasarkan kegiatan yang telah dilakukan, dapat disarankan kepada guru-guru peserta pelatihan agar menindaklanjuti secara mandiri hasil kegiatan ini dalam bentuk PTK. Pihak sekolah diharapkan terus menyebarluaskan kepada guru-guru lainnya yang tidak berkesempatan mengikuti kegiatan pendampingan agar mencoba melakukan pembelajaran dengan menerapkan model pembelajaran tri kaya parisudha. Di samping itu, memberikan kesempatan lebih banyak lagi kepada guru-guru untuk mengikuti kegiatan pendampingan yang sejenis dalam rangka meningkatkan profesionalisme guru. Pengambil kebijakan/pemerintah diharapkan merancang kegiatan yang sejenis, yaitu melaksanakan pelatihan dan pendampingan dan atau menyediakan dana untuk kegiatan tersebut. Dengan demikian, guru-guru yang belum dapat kesempatan dalam pelatihan dan pendampingan ini, bisa mengikuti pelatihan dan pendampingan pada kesempatan lain.

\section{DAFTAR RUJUKAN}

Adeyemi, M. B., Moumakwa, T. ., \& Adeyemi, D. . (2009). Teaching Character Education Across the Curriculum and The Role of Stakeholders at The Junior Secondary Level in Botswana. Stud Home Comm Sci, 3(2), 97-105. https://doi.org/10.1080/09737189.2009.11885283.

Agung, I. (2017). Peran Fasilitator Guru dalam Penguatan Pendidikan Karakter (PPK). Perspektif Ilmu Pendidikan, 31(2), 106-119. http://journal.unj.ac.id/unj/index.php/pip/article/view/4509.

Aini, S. Q., \& Syamwil, F. (2020). Konstruksi Pendidikan Karakter Siswa melalui Keteladanan Guru di Sekolah. MANAGERE: Indonesian Journal of Educational Management, 2(2), 149-156. https://lp3m.unuja.ac.id/unduh_jurnal/389/42 Siti Qurratul Aini.pdf.

Akhwani, A., \& Rahayu, D. W. (2021). Analisis Komponen TPACK Guru SD sebagai Kerangka Kompetensi Guru Profesional di Abad 21. Jurnal Basicedu, 5(4), 19181925. https://lp3m.unuja.ac.id/unduh_jurnal/389/42 Siti Qurratul Aini.pdf.

Artawan, K. N., \& Ardiawan, I. K. N. (2018). Pembelajaranquantum Teaching Berbasis Tri Kaya Parisudha. Edudikara: Jurnal Pendidikan Dan Pembelajaran, 3(2), 201-212. http://www.ojs.iptpisurakarta.org/index.php/Edudikara/article/view/100.

Artini, N. P. Y., Parmiti, D. P., \& Sudana, D. N. (2016). Pengaruh Model Pembelajaran Kooperatif Tipe Think-Talk-Write Berbasis Kearifan Lokal Tri Kaya Parisuda. Mimbar PGSD Undiksha, 4(3). https://ejournal.undiksha.ac.id/index.php/JJPGSD/article/view/8623.

Astawan, I. G. (2018). Pengembangan Perangkat Pembelajaran IPA SD Bermuatan Kearifan Lokal Tri Kaya Parisudha untuk Meningkatkan Keterampilan Proses dan Menanamkan Nilai Karakter. Universitas Pendidikan Ganesha.

Bagou, D. Y., \& Suking, A. (2020). Analisis Kompetensi Profesional Guru. Jambura Journal of Educational Management, 122-130. https://ejournal-fip- 
ung.ac.id/ojs/index.php/JJEM/article/view/522.

Benninga, J., Berkowitz., M. W., Kuehn, P., \& Smith, K. (2013). The Relationship of Character Education Implementation and Academic Achievement in Elementary School. Journal of Research in Character Education, 1(1), 19-32.

Chrisyarani, D. D., \& Yasa, A. D. (2018). Validasi Modul Pembelajaran: Materi dan Desain Tematik Berbasis PPK. Premiere Educandum: Jurnal Pendidikan Dasar Dan Pembelajaran, $8(2)$ 206-212. https://pdfs.semanticscholar.org/809d/caaa14cdd74c4b19626bba146dde1335089c.pdf

Çubukçu, Z. (2012). The Effect of Hidden Curriculum on Character Education Process of Primary School Students. Educational Sciences: Theory \& Practice, 12(2), 15261534. https://eric.ed.gov/?id=EJ987859.

Jamin, H. (2018). Upaya Meningkatkan Kompetensi Profesional Guru. At-Ta'dib: Jurnal Ilmiah Prodi Pendidikan Agama Islam, 19-36. http://ejournal.staindirundeng.ac.id/index.php/tadib/article/view/112.

Joyce, B., Weil, M., \& Calhoun, E. (2016). Models of Teaching (9th ed.). Pustaka Pelajar.

Khotimah, D. N. (2019). Implementasi Program Penguatan Pendidikan Karakter (PPK) Melalui Kegiatan 5s di Sekolah Dasar. INOPENDAS: Jurnal Ilmiah Kependidikan, 2(1). http://jbasic.org/index.php/basicedu/article/view/321.

La ode Onde, M., Aswat, H., Fitriani, B., \& Sari, E. R. (2020). Integrasi Penguatan Pendidikan Karakter (PPK) ERA 4.0 pada Pembelajaran Berbasis Tematik Integratif di Sekolah Dasar. Jurnal Basicedu, 4(2), 268-279. http://jbasic.org/index.php/basicedu/article/view/321.

Law, A. M., \& Kelton, W. D. (1991). Simulating Modelling and Analysis. Mc. Graw Hill, Inc.

Mahardika, L., Hermawan, R., \& Riyadi, A. (2017). Penerapan Model Project Based Learning untuk Meningkatkan Kecerdasan Kinestetik Siswa Sekolah Dasar. Jurnal Pendidikan Sekolah Dasar, 11(1). https://doi.org/10.17509/jpgsd.v2i1.13238.

Mahmudah, M. (2018). Pengelolaan Kelas: Upaya Mengukur Keberhasilan Proses Pembelajaran. Jurnal Kependidikan, 6(1), 53-70. http://ejournal.uinsaizu.ac.id/index.php/jurnalkependidikan/article/view/1696.

Minsih, M. (2018). Peningkatan Kualitas Profesionalisme Guru dengan Pelatihan Model Model Pembelajaran. Peran Guru Dalam Pengelolaan Kelas, 5(1), 20-27. https://journals.ums.ac.id/index.php/ppd/article/view/6144.

Muchtar, D., \& Suryani, A. (2019). Pendidikan Karakter Menurut Kemendikbud. Edumaspul: Jurnal Pendidikan, 3(2), 50-57. https://ummaspul.ejournal.id/maspuljr/article/view/142.

Mutiaramses, M., Neviyarni, S., \& Murni, I. (2021). Peran Guru dalam Pengelolaan Kelas terhadap Hasil Belajar Siswa Sekolah Dasar. Pendas: Jurnal Ilmiah Pendidikan Dasar, 6(1), 43-48. https://journal.unpas.ac.id/index.php/pendas/article/view/4050.

Rahayu, G. D. S., \& Firmansyah, D. (2019). Pengembangan Pembelajaran Inovatif Berbasis Pendampingan bagi Guru Sekolah Dasar. Abdimas Siliwangi, 1(1), 17-25. https://www.journal.ikipsiliwangi.ac.id/index.php/abdimas-siliwangi/article/view/36.

Rahmadani. (2019). Metode Penerapan Model Pembelajaran Problem Based Learning (PBL). Lantanida Journal, $\quad 7, \quad 1-100$. https://scholar.archive.org/work/hmjfac53dzexjhpkk5igi31kxy/access/wayback/https:// www.jurnal.ar-raniry.ac.id/index.php/lantanida/article/download/4440/pdf.

Sari, L., \& Firman, F. (2019). Pengembangan Model Pendidikan Karakter Terintegrasi Pembelajaran IPA Sekolah Dasar. Edukatif: Jurnal Ilmu Pendidikan, 1(3), 270-279. https://www.edukatif.org/index.php/edukatif/article/view/64. 
Sutisna, D., Indraswati, D., \& Sobri, M. (2019). Keteladanan Guru sebagai Sarana Penerapan Pendidikan Karakter Siswa. JPDI (Jurnal Pendidikan Dasar Indonesia), 4(2), 29-33. https://journal.stkipsingkawang.ac.id/index.php/JPDI/article/view/1236.

Suyono, \& Hariyanto. (2015). Implementasi Belajar dan Pembelajaran. PT. Remaja Rosdakarya.

Tibahary, A. R., \& Muliana, M. (2018). Model-model Pembelajaran Inovatif. Scolae: Journal of Pedagogy, l(1), 54-64. http://ejurnal.stkipdamsel.ac.id/index.php/scl/article/view/12.

Tristanti, L. Y., Ibrahim, M., Hidayat, T., \& Akhwani, A. (2021). Pembelajaran Karakter Terintegrasi IPA di Sekolah Dasar. Jurnal Basicedu, 5(5), 3373-3377. http://jbasic.org/index.php/basicedu/article/view/1351.

Widiasih, L. S., Suarjana, I. M., \& Renda, N. T. (2019). Pengaruh Model Pembelajaran SFAE Berbasis Tri Kaya Parisudha terhadap Hasil Belajar Matematika Siswa. Jurnal Ilmiah Sekolah Dasar, 3(2), 135-141. https://ejournal.undiksha.ac.id/index.php/JISD/article/view/17758.

Yang, M. Y., Manlai, Y., \& Chen, F. C. (2005). Competences and Qualification for Industrial Design Jobs: Implication for Design Praktice, Education, and Student Career Guidance. Elservier Ltd.

Yuliati, S. R., \& Lestari, I. (2018). Pelatihan Model-model Pembelajaran Inovatif bagi Guruguru SD di Wilayah Kecamatan Sukamakmur, Bogor. Jurnal Pemberdayaan Sekolah Dasar(JPSD), 1(1), 1-7. http://journal.unj.ac.id/unj/index.php/jpsd/article/view/9267.

Zubaidah, S. (2019). Pendidikan Karakter Terintegrasi Keterampilan Abad Ke-21. Jurnal Penelitian Dan Pengkajian Ilmu Pendidikan: E-Saintika, 3(2), 1-24. https://journalcenter.litpam.com/index.php/e-Saintika/article/view/125. 